\title{
Examples of ground support practice in challenging ground conditions at Vale's deep operations in Sudbury
}

\author{
M Yao Vale Canada Ltd., Canada
}

A Sampson-Forsythe Vale Canada Ltd., Canada

AR Punkkinen Vale Canada Ltd., Canada

\begin{abstract}
Vale has operated a number of underground mines in the Ontario division in Sudbury for over a century. During this time, numerous mining methods have been employed including cut-and-fill, drift-and-fill, post pillar cut-and-fill, modified sublevel caving, underhand cut-and-fill/drift and fill plus bulk mining methods such as vertical retreat mining (VRM)/slot-slash, uppers retreat and underhand bulk mining.

The division hosts a wide variety of orebodies of varying geometries, many of these at advanced stages of mining extraction. Consequently, the geomechanical challenges are substantial and include both gravity-driven and rockburst-prone ground failure conditions that are further exacerbated by rock mass characteristics and ever-increasing mining depths. Typically the gravity-driven scenarios include the recovery of remnant pillars in old mined out areas, mining through consolidated backfill and recovery of post-failure sill pillars. Burst-prone conditions become a challenge when mining through stiff and brittle geological structures, upon recovery of highly stressed sill pillars in narrow vein ore bodies or when mining at depths in excess of 2,500 $\mathrm{m}$ from surface. Gravity driven and stress induced ground failures may occur simultaneously. Underhand cut-and-fill for sill pillar recovery in narrow vein ore bodies are also known to involve risk from both of these failure mechanisms.

The adaptation of ground support practices has accelerated over the last two decades leading to an overall improvement in both safety and production. Several cases are presented in this paper illustrating the successful implementation of ground support practices at two of Vale's six deep mining operations in Sudbury. A particular focus of this paper will be on 153 Orebody of Coleman Mine, where highly stressed multi-sill pillars are being mined by utilising both overhand and underhand cut-and-fill mining method, and 400 and 461 orebodies of Creighton Deep, where mining takes place below 2,400 $\mathrm{m}$ from surface. The design and motivation behind the rationale for ground support design are investigated. The equipment, best mining practice and procedures are discussed, as well as products associated with each design.
\end{abstract}

\section{Introduction}

Creighton Mine is located in the Greater City of Sudbury, $19.2 \mathrm{~km}$ west of the City of Sudbury. Access to the property is gained via Regional Road No. 24 through the town of Lively from Regional Road 55 or east along No. 24 from Highway 144 just north of Highway 17 West (Figure 1). Creighton Mine comprises 15 known orebodies of which a majority of the higher grade mineralisation in the Main, West, 117, 118, 128, 125, 126, 401 orebodies has been depleted. The remaining reserves and resources at Creighton Mine are concentrated near surface in the 3 Shaft remnants, the Deep (below 2,000 m) in the 400 and 461 Orebody, Up-dip 402 Orebody mining $(1,050 \mathrm{~m}), 403$ Orebody remnants $(1,800 \mathrm{~m})$ and the recently discovered 320-330 Orebody (below 2,700 m). This paper will focus on the Deep 400 and 461 Orebody, currently being mined at depths greater than $2,400 \mathrm{~m}$ from surface.

Coleman Mine is located in the Levack Township, on the North Range of the Sudbury Basin, at latitude $45^{\circ}$ $40^{\prime} 1^{\prime \prime}$ north and longitude $81^{\circ} 21^{\prime} 1^{\prime \prime}$ west, and is about $45 \mathrm{~km}$ northwest of the City of Sudbury (Figure 1). 
Coleman is currently one of Vale's most productive mines with ore handling and materials transportation accessible with existing infrastructure. The producing orebodies include: MOB1 (Main orebody), MOB2 (Lower Main or LMOB), MOB3 (Phase 3), WOB2 (West orebody), WOB3 (Phase 3 West orebody), 153 Orebody, and the new 170 Orebody that began production in July 2011. This paper will focus on the 153 Orebody where highly stressed multi-sill pillars are being mined utilising both the overhand and underhand cut-and-fill mining methods.

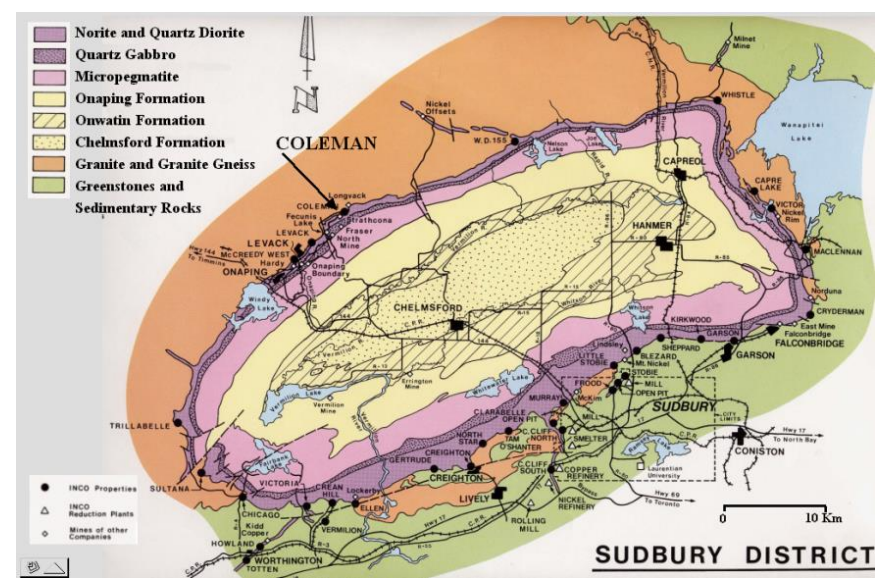

\section{Figure 1 Sudbury Basin map and location of Coleman and Creighton mines of Vale's operations}

\section{Coleman Mine - 153 Orebody}

In the 153 Orebody (OB), mining is takes place on seven horizons (4250L, 4400L, 4550L, 4700L, 4810L, $4945 \mathrm{~L}$ and $5080 \mathrm{~L}$ ) as illustrated in Figure 2. Currently there are four sill/crown pillars being mined in the 153 Orebody: 4400L Sill Pillar (bulk mining); the 4500L and 4700L Sill Pillars (underhand cut-and-fill), and 4810L Sill (overhand cut-and-fill).

Overhand cut-and-fill mining is the current primary mining method in the 153 Orebody, with bulk mining and underhand cut-and-fill mining accounting for less than $30 \%$ of production.

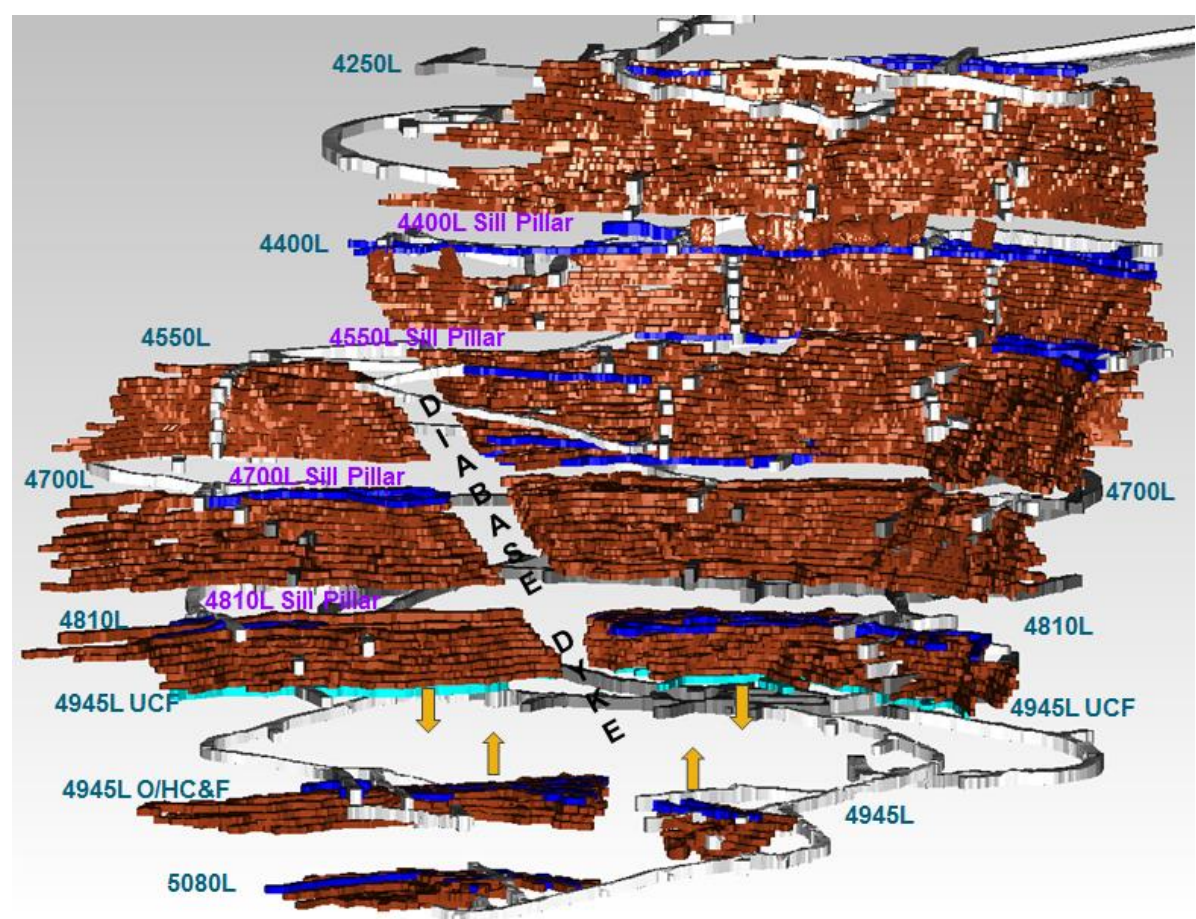


Figure 2 Longitudinal section of 153 Orebody showing mined-out areas and current sill pillar mining

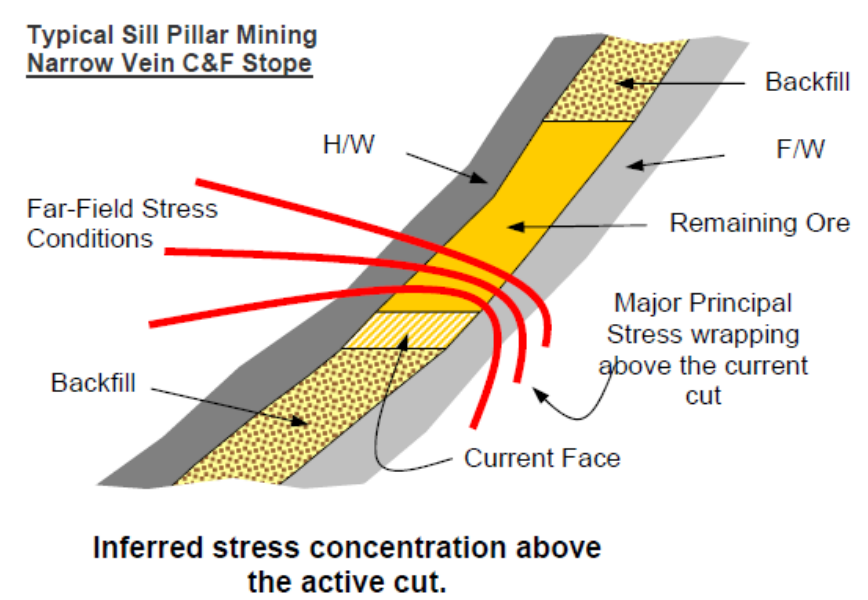

Figure 3 High stress concentration immediately above the active cut at the upper footwall and shoulder areas (Itasca Consulting Canada, Inc. 2009)

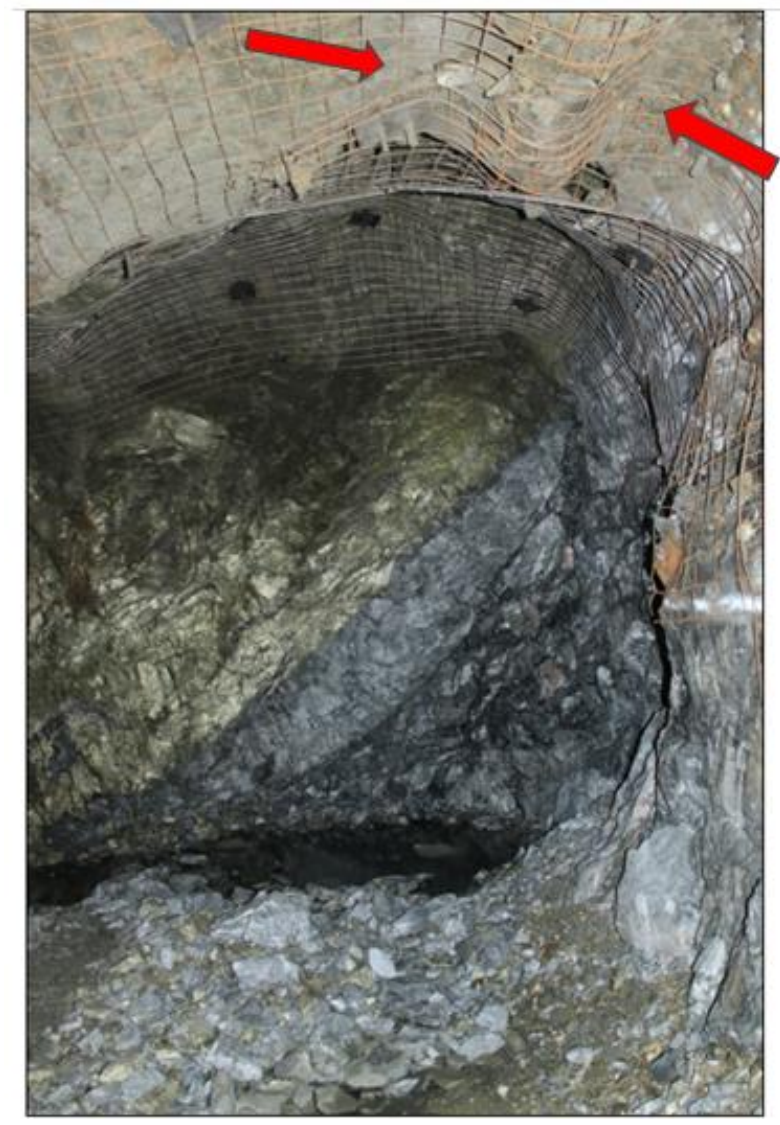

Figure 4 High stress conditions in one of the ore headings on $4810 \mathrm{~L}$ in the 153 Orebody, showing significant convergence at the upper footwall, back and shoulder area

High wrap-around stresses are associated with rockbursting conditions in the immediate footwall area and in the back of stope access drifts. The high horizontal stress results in significant convergence and crushing 
in the ore and as a consequence, secondary and additional ground support is prescribed to contain the effects of dynamic loading.

As the sill pillar becomes thinner, stresses increase significantly in the narrow orezone areas, where the ore width is considerably less than the sill pillar thickness.

- The rockburst frequency increases substantially as the sill pillars are mined from a thickness of $18 \mathrm{~m}$ to approximately $9 \mathrm{~m}$, depending upon the width of the orezone. In some areas, after the sill pillar is mined to within $9 \mathrm{~m}$ of the sill cut, the pillar begins to yield.

- Narrow orezones are of major concern because these areas normally take longer to yield.

Within the last three years or so, there has been a significant increase in seismic activity and a number of large rockbursts in both the $4550 \mathrm{~L}$ and $4700 \mathrm{~L}$ Crown Pillars have been recorded. This raises safety concerns and poses a high risk to scheduled production. All risks associated with mining in these sill pillars must be identified, with mitigation plans established to ensure that the remaining sill pillar extraction in 153 Orebody can be managed safely and efficiently.

\subsubsection{Example 1: dynamic support system in highly stressed footwall access drifts and/or footwall ore veins}

In the 153 Orebody, the type and length of back bolts is dependent on the heading span and mining method. All headings employ $1.8 \mathrm{~m}$ long back bolts, mainly resin rebar in openings less than $5.4 \mathrm{~m}$ wide and $2.4 \mathrm{~m}$ long bar for stopes between 5.4 and $7.2 \mathrm{~m}$ wide. Openings wider than $7.2 \mathrm{~m}$ usually require some form of secondary support, such as shotcrete posts. Wall bolts in all areas consist of $1.8 \mathrm{~m}$ length, $39 \mathrm{~mm}$ friction sets. \#6 gauge screen $(1.5 \times 3.3 \mathrm{~m})$ is used both in the back and walls as a part of the primary ground support.

In addition to the above primary support, a dynamic ground support system was designed based on the probability of a $3.0 \mathrm{Mn}$ (Nuttli magnitude) seismic event. A secondary support design is installed where highly stressed ground is anticipated, such as footwall (FW) ore veins and/or FW access drifts. It is also used in brow areas and for potentially unstable geological structures, and is comprised of the following (Figures 5 and 6):

- Fibre reinforced shotcrete: Tuf-Strand or Bar-chip fibre reinforced shotcrete (FRS) is currently used as a single pass system, prior to installation of the above primary ground support in rockburst prone ground conditions. A minimum $75 \mathrm{~mm}$ thick of FRS is sprayed as an initial support to reduce personnel exposure to potential strainbursts.

- Dynamic bolts with \#00 gauge welded mesh straps: Dynamic bolts, as specified below, are installed with $\# 00$ gauge, $3 \mathrm{~m}$ length $\times 0.3 \mathrm{~m}$ width mesh straps welded on a $100 \times 100 \mathrm{~mm}$ pattern:

- In intact ground, three $2.4 \mathrm{~m}$ long modified cone bolts (MCB) are installed per mesh strap with a typical spacing of $1.5 \mathrm{~m}$ between mesh straps.

- Recently, D-bolts (Li 2009) were introduced at Coleman Mine. Similar to MCB bolts, three $2.4 \mathrm{~m}$ long D-bolts are installed per mesh strap with a typical spacing of $1.5 \mathrm{~m}$ between mesh straps.

- In broken ground, four $2.4 \mathrm{~m}$ long yielding Swellex are installed per mesh strap with a typical spacing of $1.5 \mathrm{~m}$ between the mesh straps. The yielding Swellex is used as a substitute to the cone bolts.

The typical height of the drift is designed to be $2.7 \mathrm{~m}$ high in the narrow vein, where Jackleg and Stoper are used to install ground support. In order to further reduce personnel exposure to the seismic risk during and after installation of ground support, a design change in mining strategy for both $4550 \mathrm{~L}$ and $4700 \mathrm{~L}$ was 
developed in 2010, which included increasing the size of the immediate FW vein excavation to accommodate the Maclean bolter for installation of ground support (Section 2.1.2).

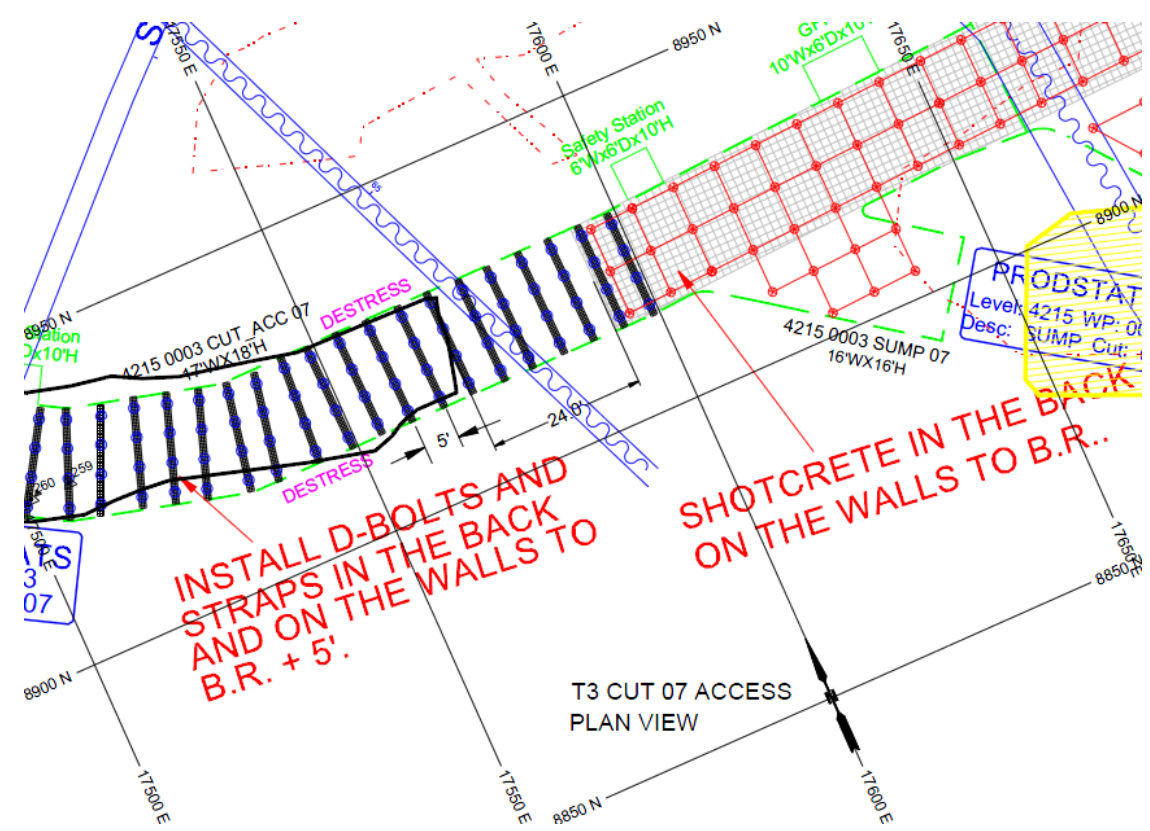

Figure 5 Dynamic support system in highly stressed FW access drift in sill pillar mining areas
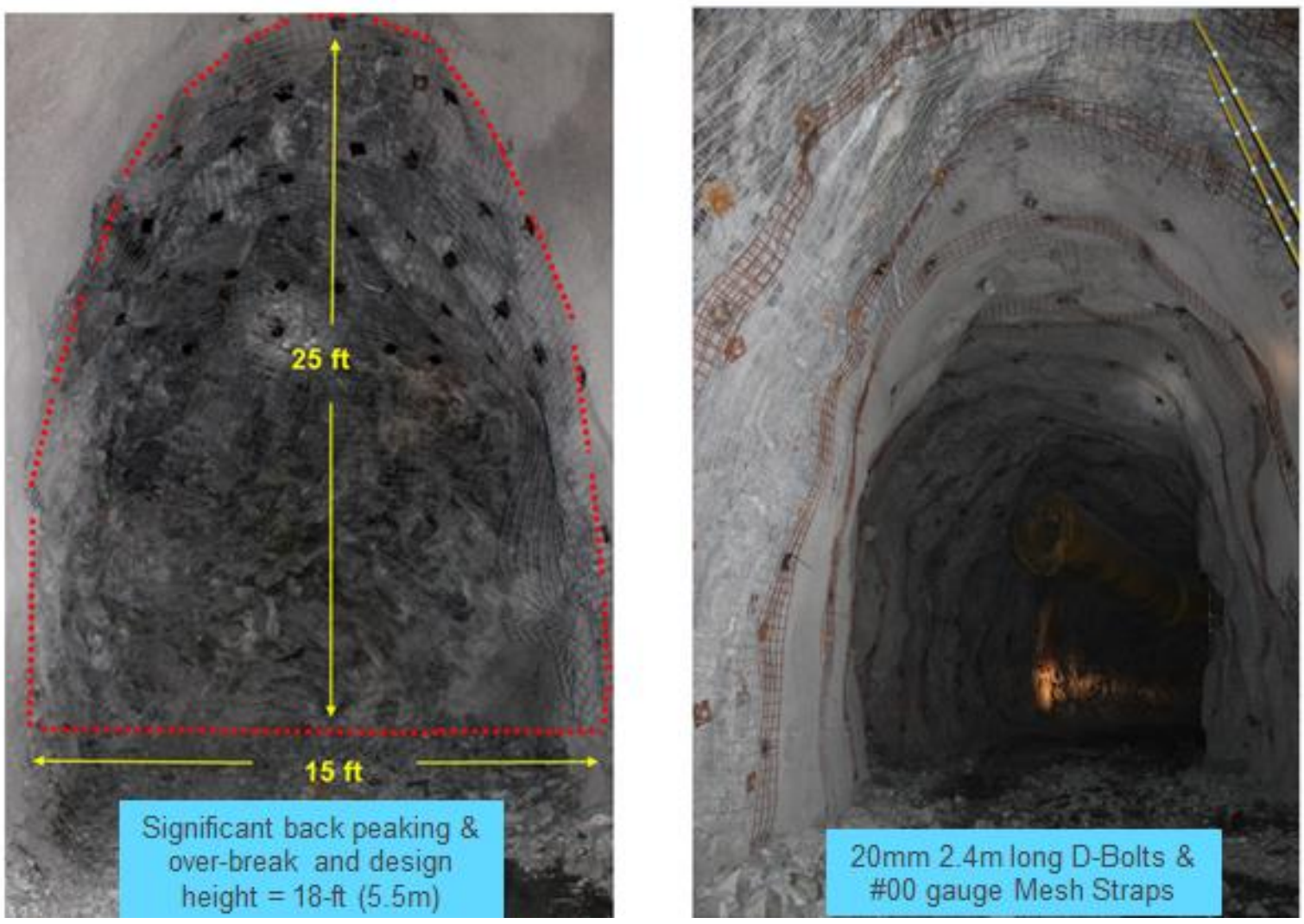

Figure 6 Dynamic support system installed in highly stressed FW access drift in sill pillar mining areas 


\subsubsection{Example 2: change of drift design to accommodate the mechanised equipment to further reduce worker exposure to seismicity}

In main footwall veins, to further reduce personnel exposure to seismicity, the heading size is increased from $3 \times 3 \mathrm{~m}$ to $4.5 \times 4.8 \mathrm{~m}$ to accommodate mechanised bolting equipment (Maclean Bolters versus Stoper \& Jack Leg). Larger footwall headings ( $4.8 \mathrm{~m}$ high and up to $7.2 \mathrm{~m}$ wide) are mined on $4700 \mathrm{~L}$ in Block 2 , Cut 12 to serve this purpose (Figures 7 and 8 ).

The dynamic support system is composed of the following:

1. First pass shotcrete of a minimum of $75 \mathrm{~mm}$ thickness.

2. \#6 gauge screen and rebar in the back and shoulders and $39 \mathrm{~mm}$ friction set bolts installed $+0.6 \mathrm{~m}$ from the floor in the FW and $+1.5 \mathrm{~m}$ in the HW.

3. \#0/0 gauge mesh straps with three MCB per strap. Another option is to install four yielding Swellex bolts per strap where the ground is fractured and it is difficult to install the MCB or D-bolts (especially in ore).

4. All support is installed 'first pass' advancing simultaneously.

5. Destressing techniques are employed in all FW drifts.

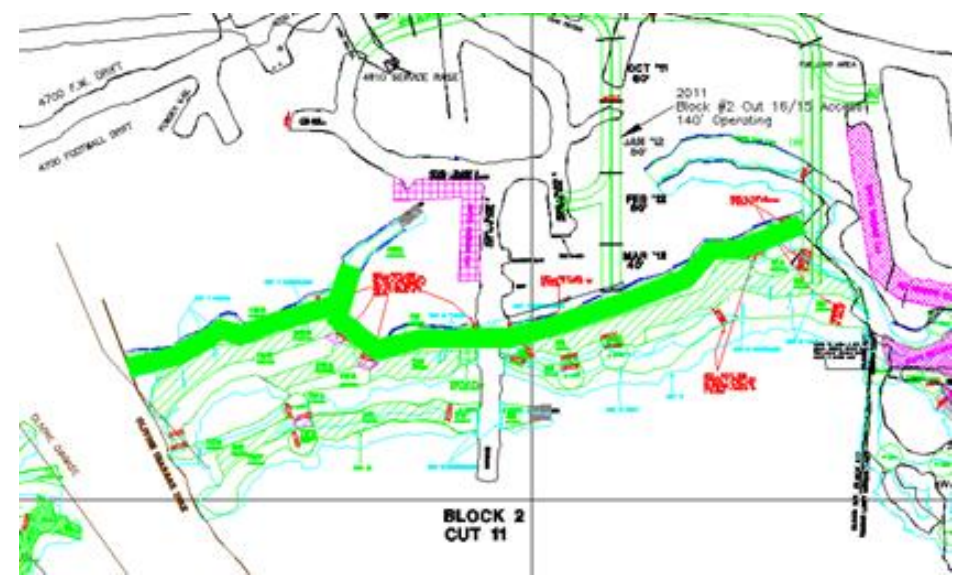

Figure 7 Change in mining strategy in 4700L Block 2 (plan view)

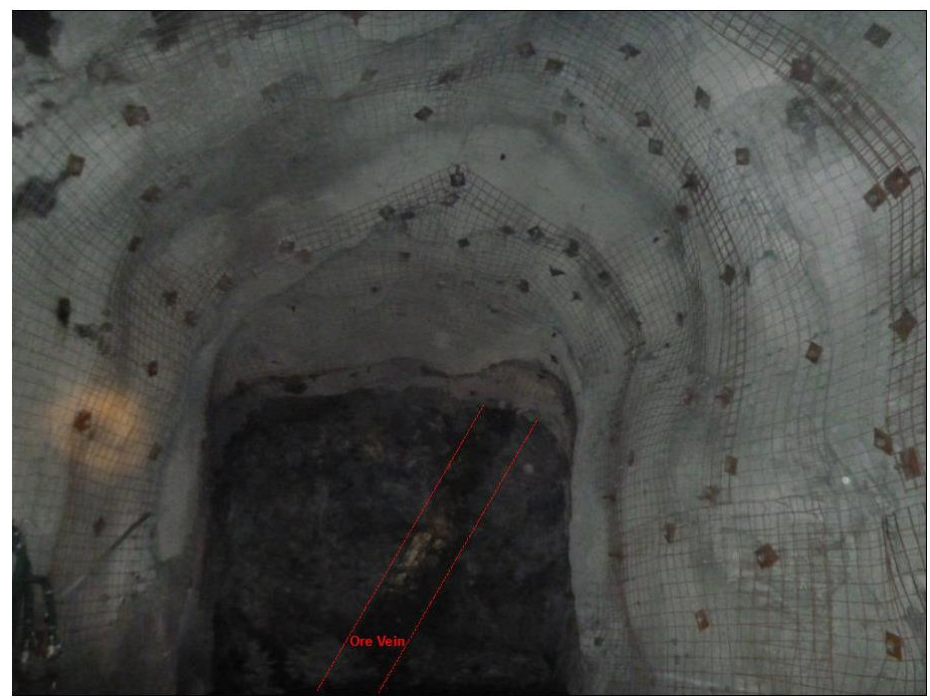

Figure 8 Dynamic ground support system installed to withstand $3.0 \mathrm{Mn}$ seismic events 
Based on Canadian Rockburst Support Handbook (Kaiser et al. 1996), an excel spreadsheet was internally developed to design dynamic support requirements at Vale (Yao et al. 2009). An example of back support design in order to withstand 3.0 Mn major seismic events is shown in Figure 9.

In general, if the dip of the ore vein is greater than $50^{\circ}$, bulk mining (also known as slot-slash, VRM, blasthole or longhole stoping) is the preferred mining method for these narrow vein orezones in high stress conditions. When the sill pillars approach $20 \mathrm{~m}$ thick, the continued suitability of the overhand cut-and-fill mining method is re-evaluated. Each horizon, or level, depending on the ground conditions, may eventually be converted to bulk mining and/or underhand cut-and-fill for sill pillar extraction as the pillars between the mined-out zones are diminished.

Geotechnical studies for the 153 Orebody were completed by Itasca and SRK (Itasca Consulting Canada, Inc. 2009; SRK Consulting 2012) to examine suitable mining strategies for the recovery of these crown pillars, specifically the determination of on which cut the overhand cut-and-fill should stop and the mining method changed to underhand mining.

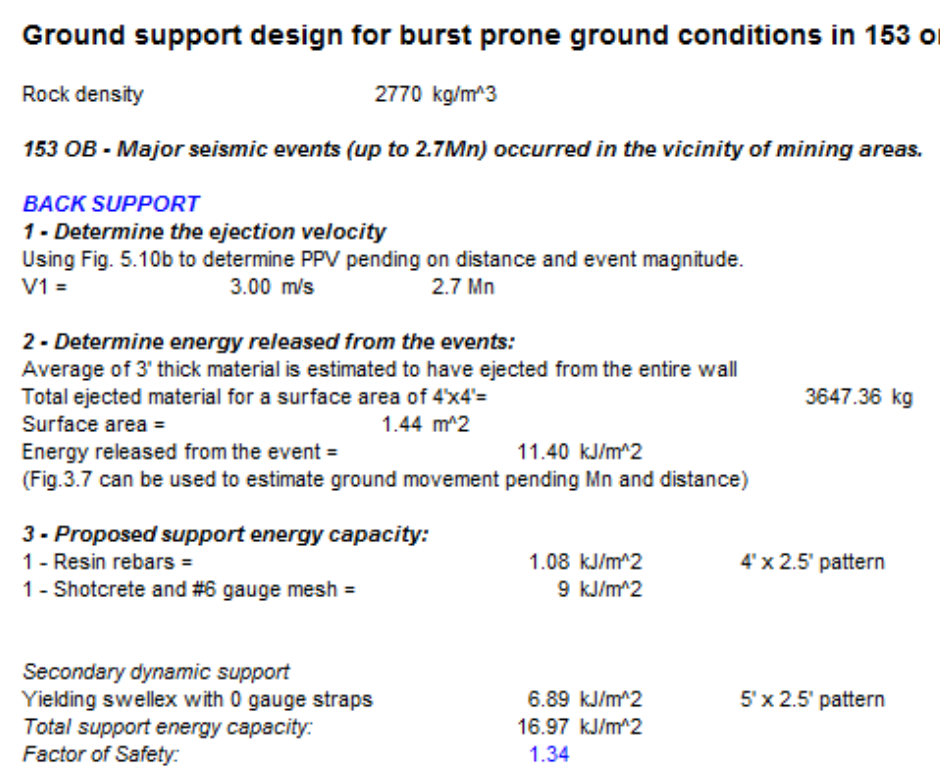
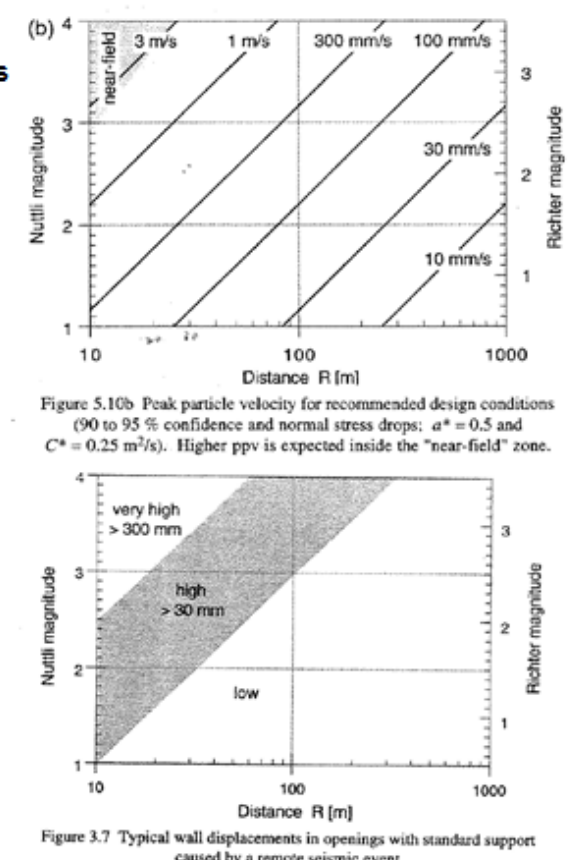

\section{Figure 9 An example of dynamic ground support system designed to withstand 3 Mn major seismic event}

\subsection{Challenges associated with underhand mining in narrow vein sill pillars}

Underhand cut-and-fill mining is fairly new to Coleman Mine and the 153 Orebody. It is a method of extracting a block of ore by mining successive $2.7 \mathrm{~m}$ high cuts, using a 'top-down' approach and filling each successive cut with cemented sand fill. Mine planning is done in a way similar to overhand cut-and-fill, using one access for two cuts. Subsequent underhand levels will have cemented backfill in an engineered sill mat above the current mining horizon. Recently, the orignal helicopter type of sill mat (Pakalnis \& Associates Consulting 2011) has been changed to Gabion type in order to enhance installation effciency (Figure 10). Prior to backfilling with 10:1 cemented hydraulic fill, an engineered sill mat will be installed in the underhand cut-and-fill stopes. The maximum span design is no greater than $4.5 \mathrm{~m}$ and the minimum time between fill placement to mining under the fill material is 28 days. The reinforced sill mat is required to minimise potential cold joints, which are zones of weaknesses in the backfill (Figure 11). The underhand cut-and-fill process is repeated until the entire crown/sill pillar is extracted.

Compared to overhand cut-and-fill, underhand cut-and-fill mining is generally a safer method of mining in high stress sill pillars due to the following factors: 
- It reduces the risk of personnel exposure to solid ground in the back which can be subject to averse seismicity.

- It allows mining to take place underneath the backfill (an engineered product) that requires a ground support system for stabilising gravity-driven risks exclusively.

The targeted areas for this mining method are the highly stressed areas and potential burst prone blocks in the 153 Orebody, such as 4550L Block 2 and 4700L Block 2.

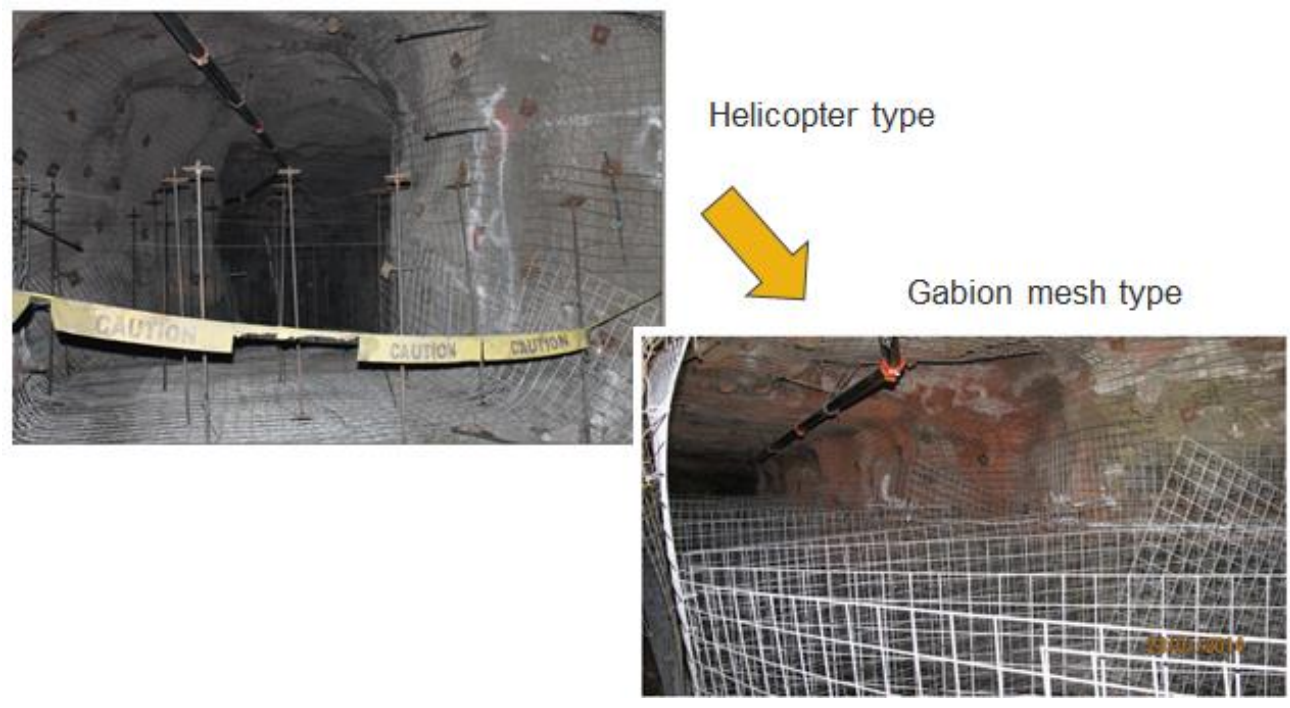

Figure 10 Change from helicopter type to gabion type reinforcing for enhancing installation efficiency

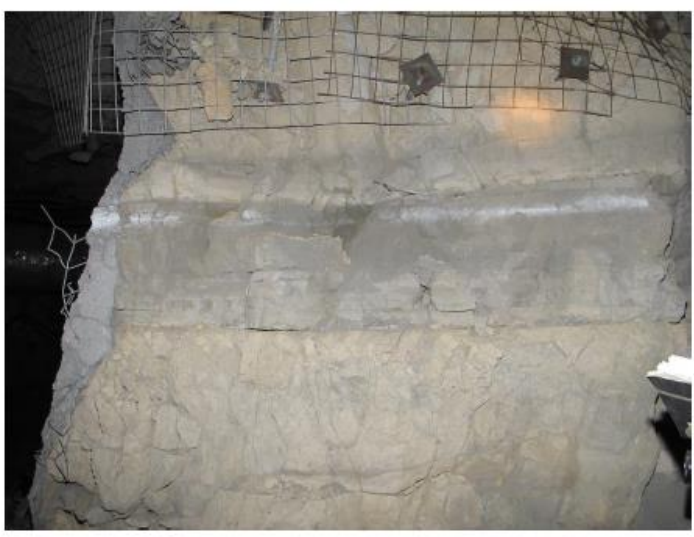

Figure 11 Segregation to form cold joints in cemented sandfill (Smith \& Palmer 2014)

\subsubsection{Example 3: ground Support Requirements for mining under Gabion Sill Mat}

The design of a ground support system when mining underneath consolidated sandfill depends on sandfill strength and quality, and the drift span itself (Figure 12). This chart is an empirical analysis which reveals that a minimum uniaxial compressive strength (UCS) of $1.0 \mathrm{MPa}$ is required for drift spans up to $4.5 \mathrm{~m}$. 


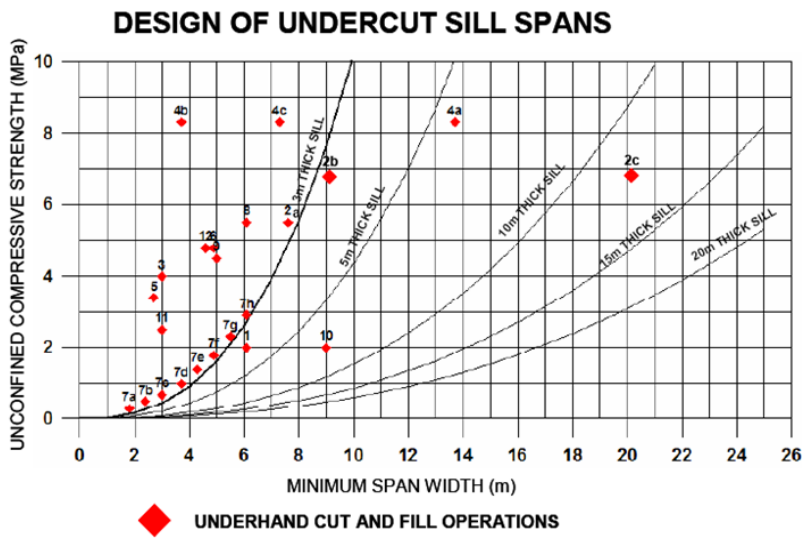

\section{Figure 12 Underhand drift spans versus backfill strength (Stone 1993)}

Ground support system and mining procedure when drifting ( $3 \mathrm{~m}$ high $\times$ up to $4.5 \mathrm{~m}$ wide) underneath the consolidated sandfill (strength $<1 \mathrm{MPa}$ at 28 days) in the underhand cut-and-fill (UCF) with Stoper \& Jack Leg is described as follows:

- Apply a minimum of $75 \mathrm{~mm}$ thick plain shotcrete or fibre reinforced shotcrete to base of rail.

- Allow shotcrete to cure a minimum of 8 hours with accelerated mix for regular shotcrete (or two hours for rapid-set shotcrete).

- Install \#6 gauge screen with $1.8 \mathrm{~m}$ long plastic-coated Swellex (Pm12) in the back and $1.8 \mathrm{~m}$ long friction sets on the walls on a $1.2 \times 1 \mathrm{~m}$ pattern. Resin rebar can be used in the back to replace Swellex in solid ground.

- Secondary support may be required depending upon the opening span.

Ground support system installed beneath the sill mat is shown in Figure 13.

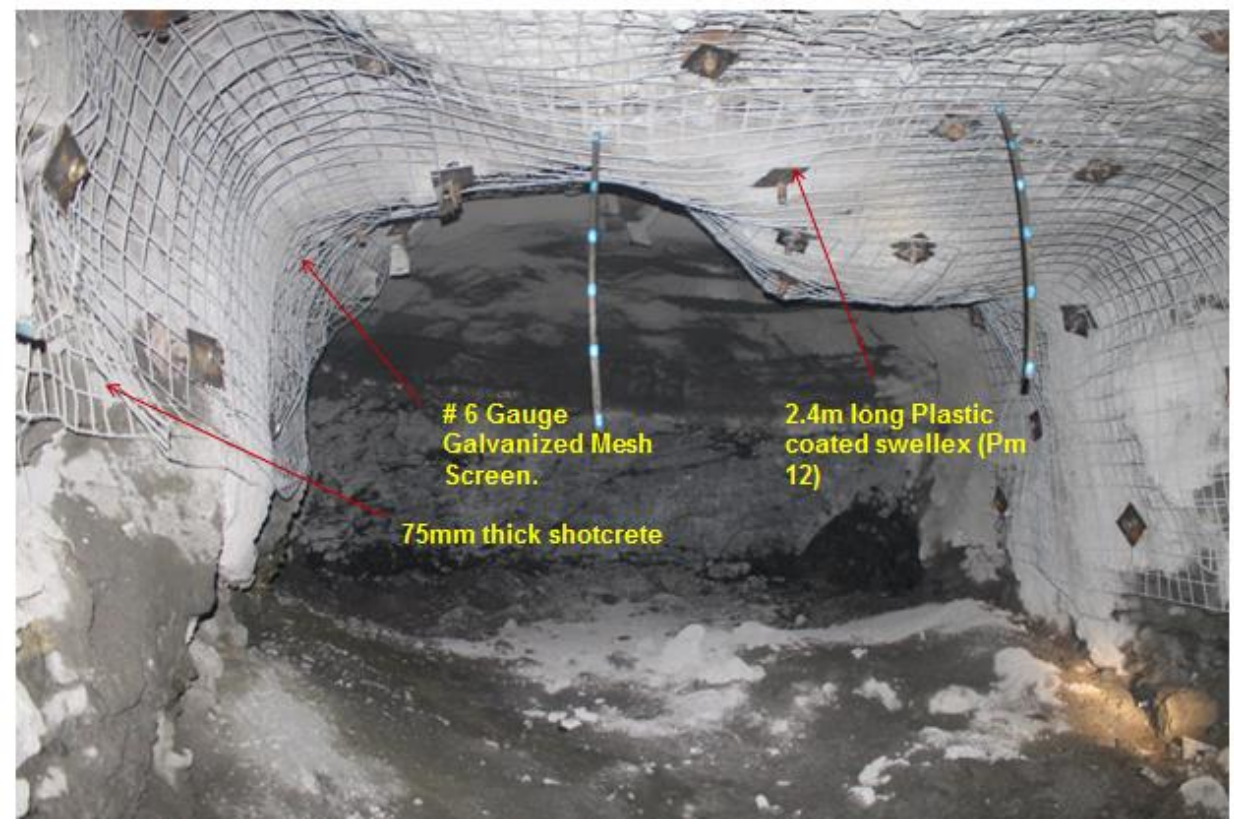

Figure 13 Ground support system installed underneath sandfill with sill mat

\section{Creighton Deep mining below 2,000 m}

A pillarless open stoping and a top-down centre-out sequence is being employed at Creighton Deep for mining below 2,000 m. As shown in Figure 14, the avoidance of pillars within a centre-out sequence pushes 
stress into the abutments as the extraction ratio increases, providing a zone of relaxation below mined out areas for development of the topsills.
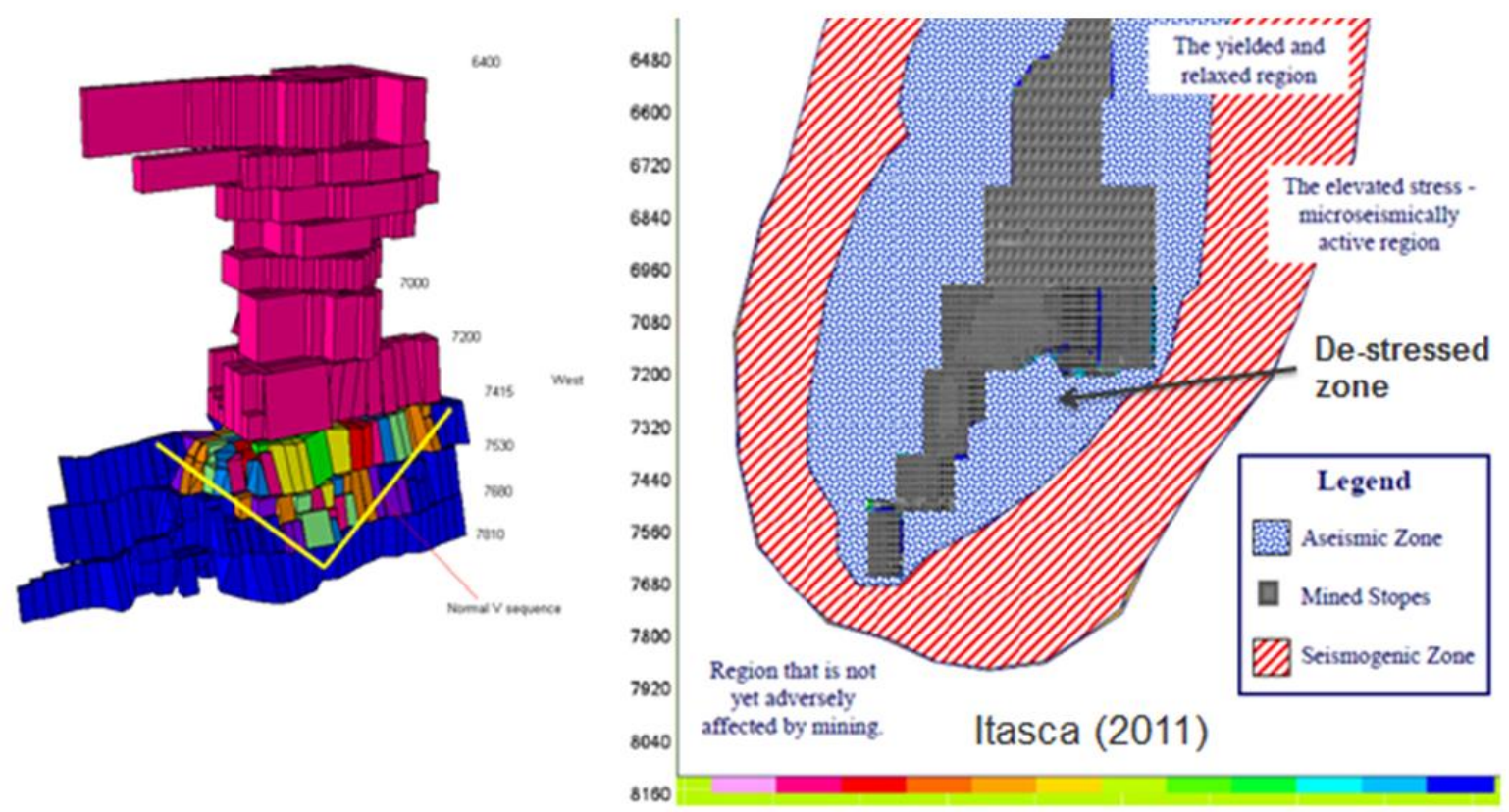

\section{Figure 14 A pillarless open stoping and a top-down centre-out sequence is being employed at Creighton Deep}

Slot and slash is currently the primary method in use at Creighton. It is recommended in areas where high stress levels are anticipated and where high levels of seismic activity are generated. Production panels, in general vary in size from $8 \times 12 \mathrm{~m}$ to $12 \times 24 \mathrm{~m}$ depending on geometry and ground conditions. Hole diameters are 0.165 or $0.114 \mathrm{~m}$ and are typically drilled from $18-45 \mathrm{~m}$ in length. Slots are created using a $1.219 \mathrm{~m}$ diameter raise bore hole, up-reamed through a $0.228 \mathrm{~m}$ pilot hole or alternatively blasted using a 'rapid raise' method whereby a slot is created by blasting into a cut created by reaming a series of $0.165 \mathrm{~m}$ holes to $0.254 \mathrm{~m}$ diameter.

Following creation of the slot, ore is blasted into the void in vertical slices. The blasts are initiated with electronic detonators extracting the ore in blocks typically the width of the stope in lifts as high as $7 \mathrm{~m}$. Practices are in place to prevent the oxidation of high-grade bulk material and all blasts are recorded by a stationary blast monitor located approximately 100 to $300 \mathrm{~m}$ from the production area. Waveforms are analysed by planning, geotechnical personnel and the blast co-ordinator in charge to evalute the effectiveness of each blast and develop changes for continuous improvement.

Increased stress levels associated with mining at depth requires extra measures to control violent rockburst episodes associated with large-magnitude seismic activity. Primary support for a standard drift of $5 \times 5 \mathrm{~m}$ at Creighton Deep consists of:

- Back/shoulders: $2.4 \mathrm{~m}$ length $20 \mathrm{~mm}$ rebar bolts installed with a square $150 \times 6.4 \mathrm{~mm}$ dome washer plate on a $1.2 \times 1.5 \mathrm{~m}$ staggered (3-2-3) bolt pattern through \#4 gauge galvanised welded wire mesh (GWWM).

- Walls: $2 \mathrm{~m}$ length, $46 \mathrm{~mm}$ friction set bolts with a dome washer plate and \#4 GWWM are installed to within $1.5 \mathrm{~m}$ of the floor elevation a minimum $3.5 \mathrm{~m}$ from the face.

Creighton Mine has been using \#4 gauge welded wire mesh for several decades. Tests completed at MIRARCO demonstrate the superiority of higher gauge mesh (Maybee 2001). Coupled with FS46 
installation, \#4 mesh provides superior support against dynamic loading (Punkkinen 2012). Effectiveness in pillar and strainburst conditions is shown in Figure 15.
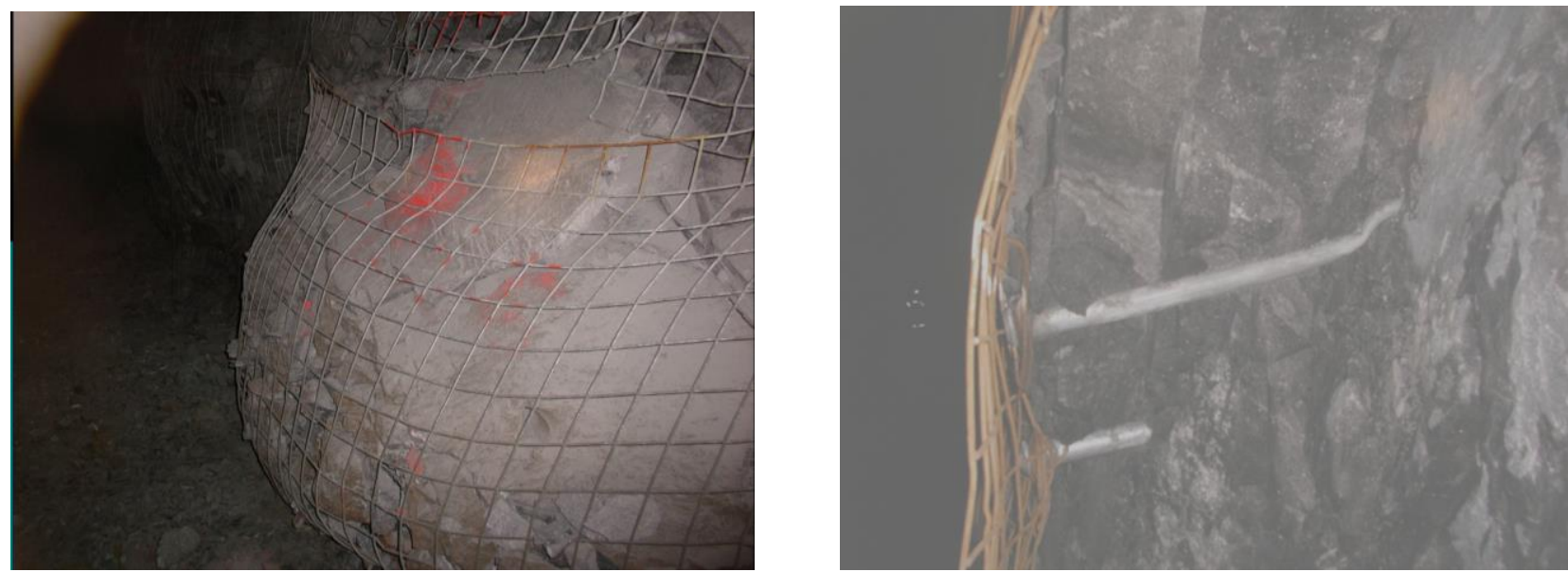

\section{Figure 15 Superior performances of \#4 gauge welded wire mesh and FS46 bolts after a major seismic event}

\subsection{Example 4: first pass dynamic support in burst-prone conditions}

In the past, dynamic support was installed exclusively as a secondary pass. Over time, the need for dynamic support for the primary support stage became a priority. With increasing depth of development, design changes were implemented to increase the level of safety for personnel. New, enhanced support components made it possible to effectively install this type of support in the initial bolting stage without detrimental impact to the development cycle. A dense pattern of stiff/dynamic support was implemented with safety factors exceeding that of the secondary support system as determined by wedge block analysis and Canmet test results for ground support components (Figure 9). The first pass system consists of the following ground support components as shown in Figure 16:

- In the back and shoulders: \#4 gauge $(1.5 \times 3.4 \mathrm{~m}) \mathrm{GWWM}$ is installed with alternating rows of $2.4 \mathrm{~m}$ length $20 \mathrm{~mm}$ rebar and modified cone bolts (MCB33) on a 4-3-4 bolt pattern. Each dome plate is supplemented with a single \#0/0 gauge $300 \mathrm{~mm}$ mesh square to provide additional surface support.

- On the Walls: \#4 gauge screen is installed with alternating rows of $2 \mathrm{~m}$ length $46 \mathrm{~mm}$ friction set bolts on a 3-2-3 pattern with a dome plate. Where stress conditions warrant, 2.4 m MCB33 may be substituted in the upper wall portion of an excavation. 


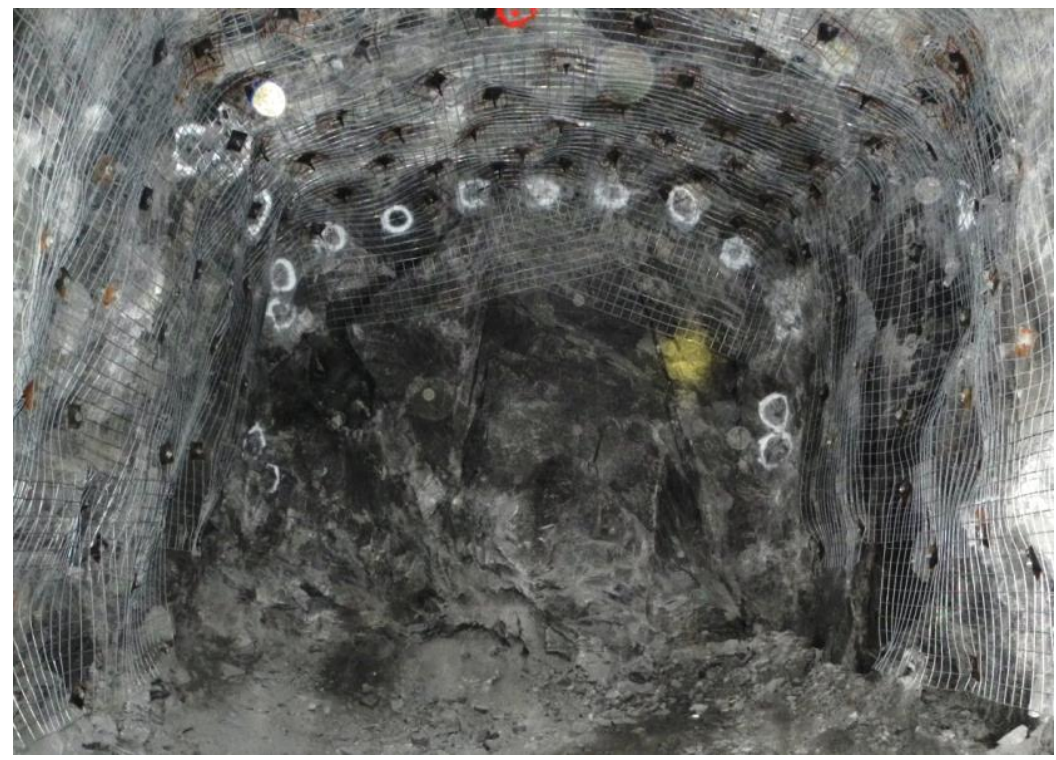

\section{Figure 16 First pass dynamic support system at Creighton Deep}

The current first-pass enhanced support system has proven to be very effective in the prevention of rockburst damage at Creighton Mine. Examples are well documented for fault-slip and strainburst, as well as pillar burst categories.

Recently a localised fault-slip event resulted in the displacement of material in an unsupported round shortly after it had been blasted in down ramp development at the 2,470 m level elevation. This event was attributed to movement along a shear zone as observed by horizontal movement of the surrounding rock mass in the back. Substantial bulging over a $20 \mathrm{~m}$ length was observed along with random rebar and an MCB33 failure. Observations of the bolt failures occurring 0.3-0.5 $\mathrm{m}$ from the collar and physical movement of the back over the top of previously installed bolts, confirm that a strong shear component was involved. The support system prevented collapse of the back, rehabilitation was issued and development quickly resumed.

Several other examples of support performance exist but are beyond the scope of this paper.

\subsection{Example 5: secondary dynamic support for major infrastructure}

Recently, the secondary dynamic support system for major infrastructure has been changed from $2.4 \mathrm{~m}$ MCB33 with \#0/0 gauge mesh straps to $2.4 \mathrm{~m}$ MCB33 with \#4 gauge mesh and \#0/0 gauge $300 \mathrm{~mm}$ squares over shotcrete (Figure 17). The secondary system is applied over the standard primary bolting system with full shotcrete. This change provides increased protection against spalling of mesh reinforced shotcrete between dynamic support elements, whilst optimising installation time. Although shotcrete remains an integral part of the ground control system for major infrastructure, shotcrete spalling and cracking due to bulking has become an issue in high stress ground as mining reaches greater depths.

Enhanced support for infrastructure is a key component in the Creighton Mine protocol for a significant seismic event. The first order of evacuation is to refuge stations, located away from the highest stress areas of the mine as determined by numerical modelling, the seismic database and derivatives such as hazard mapping and mXrap (Australian Centre for Geomechanics 2014). 


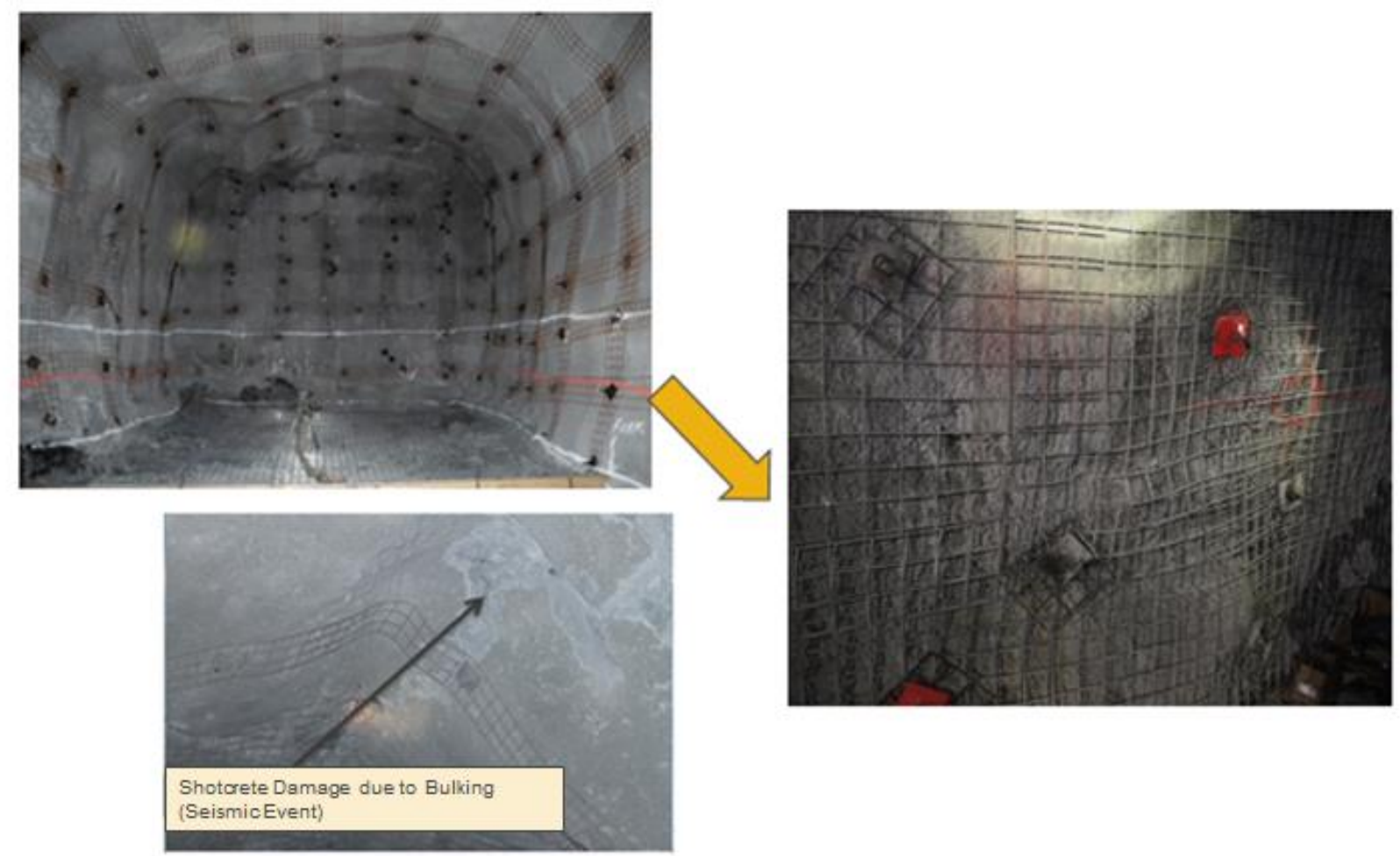

\section{Figure 17 Change of secondary dynamic support for major infrastructure}

\subsection{Example 6: ground support beneath consolidated sandfill stopes using Atlas Copco's Boltec}

In the past, topsill development under backfilled stopes not previously prepared with under-cut-and-fill methods was a labour intensive routine involving short development round lengths and two pass shotcrete. The method met limited success in VRM pillar recovery development of mechanised cut-and-fill complexes (MCF) between the 1,830 $\mathrm{m}$ and 2,130 $\mathrm{m}$ level horizons at Creighton Mine. Development through sandfill was required in the initial cut through cross-over areas where one MCF complex connected another.

In the 1980s, topsill design below 2,130 m level elevation left a $6 \mathrm{~m}$ skin of ore above the back for bolting into solid. This plan eventually proved to be problematic however, with convergence of the walls an issue due to the high stress regime at this location below the mined-out, top-down production front. Rock disposal into the bottom-sills prevented any changes at this stage of mining. Consequently, future mining below 2,250 $\mathrm{m}$ was engineered with a cemented plug of hydraulically placed 15:1 or 10:1 mine tailings and slag-cement mix to allow development directly under the backfill. Stopes were filled to a minimum $3.1 \mathrm{~m}$ above the future back elevation of the topsill providing 28 day fill strength of approximately $1 \mathrm{MPa}$.

With the introduction of the Atlas Copco Boltec, the system evolved from a one-pass shotcrete using $100 \%$ $35 \mathrm{~mm}$ friction set bolts to first secure the \#4 gauge mesh followed by a second pass of Mn12 Swellex and $\# 0 / 0$ gauge straps. The current ground support system when drifting ( $5 \mathrm{~m}$ high $\times 5 \mathrm{~m}$ wide) underneath consolidated sandfill for the top sill of bulk mining is described (Figure 18):

- Install \#4 gauge screen with $2.4 \mathrm{~m} \mathrm{Mn24}$ plastic-coated Super Swellex in the back in sand or solid/sand with FS46 on the walls to the floor on a $1.2 \times 1.5 \mathrm{~m}$ staggered pattern (eight bolts/ $1.5 \times 3.4 \mathrm{~m}$ screen) using the Atlas Copco Boltec. A $43 \mathrm{~mm}$ bit is used for Swellex in sandfill (48 $\mathrm{mm}$ in rock).

- Apply a minimum of $75 \mathrm{~mm}$ plain shotcrete to cover all screen to the floor each round (maximum length $3.6 \mathrm{~m}$ ). 
- Allow shotcrete to cure a minimum four hours with accelerated mix before drilling the next round.

- At intersections, with spans in excess of $8.5 \mathrm{~m}$, either 3 or $3.6 \mathrm{~m}$ long plastic-coated Mn24 Super Swellex are installed as a secondary support.
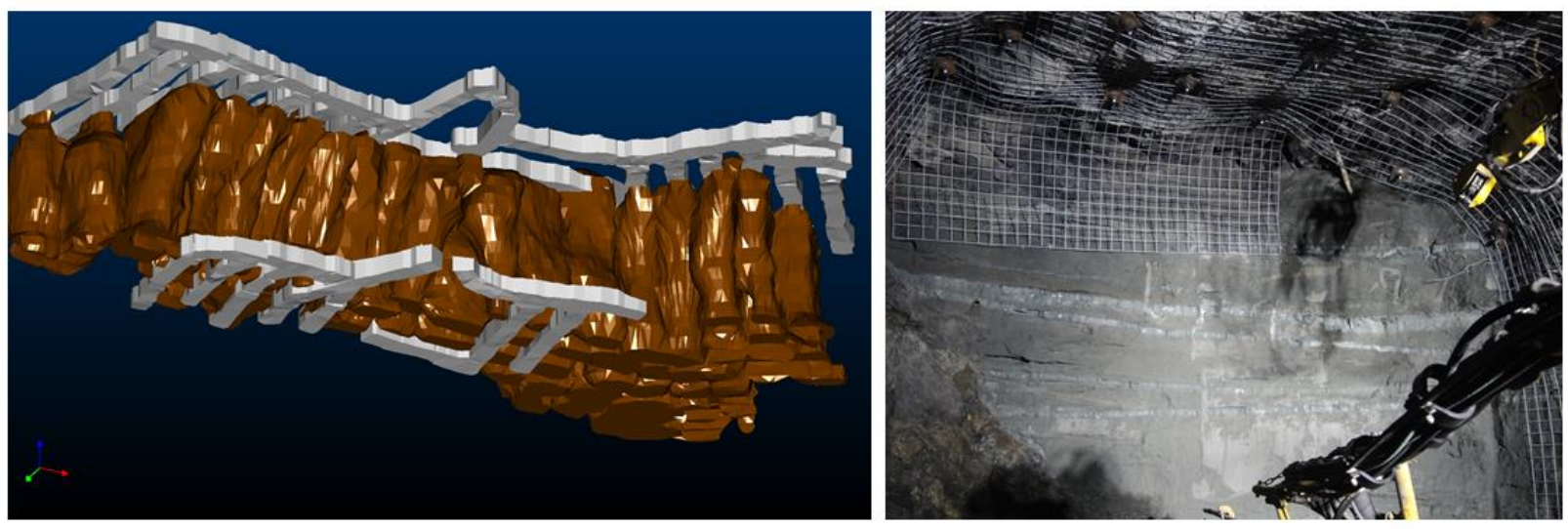

\section{Figure 18 Development and ground support under consolidated sandfilled stopes}

The system has been very successful over the period of approximately 10 years. Initial problems with longitudinal design resulted in under-cutting of high grade pillars with production. A transverse approach began below 2,300 $\mathrm{m}$ preventing undercutting of topsills has been very successful (Figure 18).

\section{Conclusions}

This paper presented the ground support systems in use at two challenging areas at Vale's Ontario Operations: In multiple sill pillar mining configuration in the 153 Orebody at Coleman; and at high stress regimes at Creighton Mine below 6400L, 2,000 m depth.

These systems reflect our current practice at Vale's the other mining operations in Ontario for safe production when dealing with similar ground conditions.

In designing ground support systems in highly stressed ground, one of the critical factors (i.e. the reduction of worker exposure to seismicity is to consider the use of mechanised equipment where feasible.

Although shotcrete remains an integral part of the support system in highly stressed ground, shotcrete spalling and cracking, depending on the failure mechanism, has become an issue when mining at everincreasing depths. Surface ground support, such as welded wire mesh, must be provided on top of the shotcrete to prevent falls of shotcrete due to seismicity.

The above mentioned support systems have been demonstrated to be successful at Vale's operations. At the design stage, extraction of the ore reserves has been economically optimised while adhering to critical factors associated with seismicity and rockbursting through:

- Optimisation of mining sequences.

- Utilisation of hazard map tools for identification of high risk zones.

- Microseismic and blast monitoring.

- Application of destress techniques.

Face support guidelines have been implemented at all of Vale's Ontario Operations mines. 


\section{Acknowledgement}

The authors express their appreciation to Samantha Espley, Steve Runnalls and Andre Lauzon at Vale's Ontario Operations for granting permission to make this presentation. Operational input and collaboration in developing these support systems at both Coleman and Creighton mines are greatly appreciated.

\section{References}

Australian Centre for Geomechanics 2014, mXrap, Australian Centre for Geomechanics, Perth, http://www.mxrap.com

Itasca Consulting Canada, Inc. 2009, 153 Orebody Mining and Geotechnical study for 4550 and 4700 levels crown pillar recovery, unpublished report submitted to Vale, Itasca Consulting Canada, Inc., Sudbury.

Kaiser, PK, McCreath, DR \& Tannant, DD 1996, Canadian Rockburst Support Handbook, Mining Innovation Rehabilitation and Applied Research Corporation, Sudbury.

Li, CC \& Doucet, C 2009, 'Performance of D-Bolts Under Dynamic Loading', Rock Mechanics and Rock Engineering, vol. 45, no. 2, pp. 194-204.

Maybee, G 2001, Static and Dynamic Testing of Weld Wire Mesh, report submitted to Robert Gustas, INCO Ltd., Geomechanics Research Centre / Mirarco

Punkkinen, A \& Yao, M 2012, 'Change of ground support system and mining practice in the Deep at Creighton Mine', Proceedings of the CIM Mining Conference \& Exhibition 2007, Canadian Institute of Mining, Metallurgy and Petroleum, Westmount.

Pakalnis \& Associates Consulting 2011, Report on Sill Mat Design for the 153 OB/MOB at Coleman, unpublished report submitted to Vale, Pakalnis \& Associates Consulting.

Smith, S \& Palmer, P 2014, Review: Support Requirements for Mining Under a Gabion Sill Mat at Vale Coleman 153 OB, unpublished report submitted to Vale, Golder Associates.

SRK Consulting 2012, Coleman Mine 153 Orebody 4810 to 5080 Level Geomechanical Study, unpublished report submitted to Vale.

Stone, DMR 1993, 'The optimization of mix designs for cemented rockfill', in HW Glen (ed.), Proceedings of the Fifth International Symposium on Mining with Backfill, South African Institute of Mining and Metallurgy, Johannesburg, pp. 249-53.

Yao, M, Chinnasane, DR \& Harding, D 2009 'Mitigation Plans for Mining in Highly Burst-Prone Ground Conditions at Vale Inco Copper Cliff North Mine', in M Diederichs \& G Grasselli (eds), Proceedings of the 3rd Canada-US Rock Mechanics Symposium \& 20th Canadian Rock Mechanics Symposium, 2009 CIM Annual Conference; Rock Engineering in Difficult Conditions: ROCKENG09, Canadian Rock Mechanics Association, paper 4045. 